\title{
On the Reform of Introduction to Computer Science under the Mode of School-Enterprise Cooperation
}

\author{
Xiujuan Sun \\ College of Information Science and Technology \\ Taishan University \\ Taian City, China \\ juanzi_5588@126.com
}

\begin{abstract}
Introduction to computer science is a basic course of computer majors. The traditional curriculum teaching is not linked to professional background, and the teaching content is obsolete. Adapting to the application-oriented talents training and schoolenterprise cooperation, the paper aims to discuss how to reform the teaching content and the teaching model of introduction to computer science course.
\end{abstract}

Keywords-introduction to computer science; school-enterprise cooperation; application-oriented talents training

\section{INTRODUCTION}

At present, many universities are not clear in the setting of training target, and have the old teaching content and teaching mode. Students are confused about the prospect of professional development and lack of professionalism. In order to change the current situation and cultivate application-oriented talents training of the information discipline, the school-enterprise cooperation mode is widely promoted in computer majors. In this context, introduction to computer science as a professional basic course for students who just enter the computer majors, how to realize its professional importing function is worth exploring.

\section{REFORM THE TEACHING CONTENT}

Introduction to computer science is a course combining theory with practice. It introduces the basic content and important applications of main computer science courses, and macroscopically discusses the inner link between these courses. In order to truly realize the professional importing function, introduction to computer science should reform the teaching content in following aspects.

\section{A. Depict the Main Line of Professional Courses}

Introduction to computer science introduced mainly computer system, computer network and computer applications. Its main content includes knowledge system of computer majors, computer history, computer system structure, computer network, operating system, database, software engineering, computer security, etc.

Under the mode of school-enterprise cooperation, the whole design of the course should be linked to professional background. Depicting a main line of professional courses can help students to clear main content of computer majors, professional development prospects, and employment market demand when students just come into contact with the computer majors. It can also arouse students' learning enthusiasm. During college, students follow the main line to learn, develop targeted themselves, and then use what they have learned to solve practical problems in the computer field.

\section{B. Improve Learning Ability}

"Give a man a fish and you feed him for a day. Teach a man to fish and you feed him for a lifetime." Teachers should not only teach students knowledge and skills, but also improve their independent learning ability.

1) Draw inferences about other cases from one instance

The method and the thought are highly unified in the computer field, so thought is more important than knowledge. For example, after explaining the ability of Shift key in selecting multiple consecutive files, teacher should guide students to apply this kind of thought to similar aspects, such as selecting continuous multiple folders, continuous text and so on.

\section{2) Summary}

Being good at summarizing is to find out the nature and law of the problem, and then solve the problem. For example, after explaining the insertion and editing of objects in Microsoft Word, teacher may guide students to summarize the law and discover the operation methods of the objects in Excel or PPT. 


\section{3) Solve problem}

Knowing why is more important than knowing what. By setting traps or obstacles in the teaching process, the teacher guides the students to analyze the cause of the problem and find the solution. This method can transform the difficulty into the learning motivation, and deepen the understanding and memory of knowledge. For example, at the beginning of learning Excel, some incomprehensible outputs will be found when entering the data such as the fraction and the id number. Let students bring the puzzle to analyze the causes of the problem, and then find solutions to the problems. In the process, the knowledge will be eventually internalized the ability solving problem.

\section{4) Comprehensive application}

The purpose of school-enterprise cooperation is to jointly cultivate application-oriented talents. Knowledge and skills are not mutually independent in practical application. So the design of teaching should emphasis the coherence and comprehensiveness between courses [1]. Teacher can even take a concrete project implementation as an example to show students how to solve practical problems with a variety of knowledge and skills. Logical thought training is indispensable in this process. Because a lot of knowledge has something in common, being good at discovering them, and using them to learn new knowledge is necessary and important.

\section{Develop Professional Interest}

Under the mode of school-enterprise cooperation, the teaching content should fully reflect the applied value in every aspect of life. For example, the database can handle with large amounts of data through the association between the data. The database has been applied to many fields, such as teaching management system, medical system, online shopping platform, etc. The applied value of knowledge should be related to the issues that students pay close attention to. For example, Introduction to computer science may introduce which courses should be learned if you want to develop the APP by yourself. Holding applied value in the brain, students will be more interested in learning.

Draw Forth Career Goals. The school-enterprise cooperation can help students to really grasp the employment direction and trend of computer majors. There are many fields of computer professional employment, such as web application design, database management, multimedia application, mobile application development, software testing, network system management, etc. Different employment direction needs different knowledge and skill. After identifying career goal, learning is more targeted. Students will be more competitive and more likely to get a job after graduation.

At the same time, in order to achieve career goals more quickly and better, it is necessary to focus on the training of teamwork and innovation ability. Because these abilities are very important in the future career.

\section{ReForm The TeACHING ModE}

In order to cooperate with the new teaching content, the teaching mode should be reformed in following aspects.

\section{A. Responsibility of Teacher}

Under the mode of school-enterprise cooperation, teachers not only teach knowledge included in this course, but also should have a basic understanding of the main computer courses. When designs the course, teacher should consider where the applied value of each main course is, what the relationship between the courses is, what knowledge should be applied to solve a specific computer problem, how match the employment direction and the skills needed, etc. These thoughts should be threaded through the curriculums.

Not only university is shortage of practical teaching materials, but also teachers' experience in professional practice has yet to be improved [2]. School-enterprise cooperation can bring teachers into corporate positions to broaden their vision and improve their practical ability [3]. After training, the teachers will come back with new knowledge and skills, and then spread them to students. Teachers can even bring practical instances to students from enterprise, import the main line of courses, employment goals and the required professionalism.

\section{B. Responsibility of Enterprise}

Education in colleges not only is weak in practice, but also lags in updating information and knowledge. The appearance of school-enterprise cooperation is to solve the problem. The company is responsible for explaining career planning and professionalism to freshmen, and launching expanding activities to cultivate students' teamwork ability. The enterprise organizes actual training, even brings the student into the real work environment to understand the whole process of the project development. In this process, the company will introduce the knowledge, skills, teamwork ability and innovation consciousness needed by the position, and add more updated data to the teaching. This employment-oriented education is more likely to be accepted by students. Students can early understand post and clear employment objective by the education.

\section{Culture Integration}

Campus culture and corporate culture have similarities and differences. The school wants to transfer the application-oriented talents to the society, which requires school to integrate the excellent corporate culture with the campus culture in the process of 
teaching [4]. In this cultural atmosphere, the values and behaviors of students are more in line with the quality requirements of the post [4]. The teaching content should be linked to the standard needed by job, the teaching process should be linked to the production process, and the students' professional quality should be linked to the job requirements. Such practical talent training program will achieve its target.

The introduction of corporate culture mainly embodies in time sense, teamwork consciousness, learning methods, cost consciousness, safety awareness and quality consciousness [5]. The methods of introducing corporate culture include corporate visits, corporate culture training, and theme class meetings about corporate culture. Through organizing these activities, the students are exposed to the corporate culture in advance, which will improve their overall quality.

\section{SUMMARY}

In order to adapt to the need of applied talents training, the teaching of introduction to computer science must be reformed deeply from content to mode. The introduction to computer science course under the mode of school-enterprise cooperation is not only to import the basic knowledge of computer, but also to import the professional development direction, learning method, logical thought and corporate culture. The school and the enterprise should jointly educate the students. The target of applicationoriented talents training should be carried through the curriculum. The professional development thought should be instilled to the students in the teaching.

\section{REFERENCES}

[1] Yinjuan Wen, Wenjuan Li, "On the reform of C language program design course in animation major of higher vocational colleges under school-enterprise cooperation-A case study on Dingxi normal college,” Journal of Hubei University of Education. Gansu, vol. 33, pp. 129-132, February 2016.

[2] Yunjie Tu, Yang Bai, "On the reform of practical teaching in computer majors based on the application-oriented talents training target," Journal of Hulunbeier University. Hailaer, vol. 24, pp. 107-109, June 2016.

[3] Ting Yu, Jianhua Wang, "Study on college-enterprise cooperation in practical teaching of computer majors," Computer Education. Haerbin, no. 15, pp. 4749, 2009.

[4] Lina He, "Strategies of integrating corporate culture into higher vocational colleges under the mode of school-enterprise cooperation," Journal of Kaifeng Institute of Education. Panjin, vol. 34, pp. 181-183, August 2014.

[5] Peiming Fu, "On the integration of campus culture and corporate culture under the mode of school-enterprise cooperation," Chinese Vocational and Technical Education. Beijing, no. 25, pp. 26-28, 2011. 